Universidad de Lima

Facultad de Derecho

Carrera de Derecho

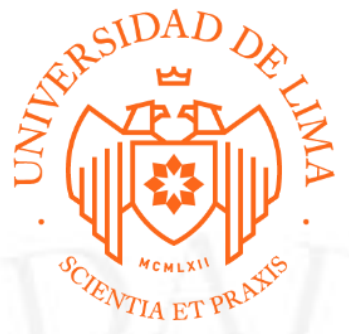

\title{
CIVIL: "OTORGAMIENTO DE ESCRITURA PÚBLICA" Y ADMINISTRATIVO: "ADMINISTRATIVO CONTENCIOSO"
}

Trabajo de suficiencia profesional para optar el Título Profesional de Abogado

\author{
Luis Abraham Garrido Huamán
}

Código 20051746

Lima - Perú

Junio de 2019 
Materia: Otorgamiento de Escritura Pública

$\mathrm{N}^{\circ}$ de Expediente: 37958-2006-0-1801-JR-CI-17

Resumen:

Se trata de un caso en el que el accionante formula una demanda de Otorgamiento de Escritura Pública, contra una empresa, en calidad de entidad liquidadora de una constructora e inmobiliaria, por los fundamentos que detalla en su demanda.

Materia: Contencioso Administrativo -

Nulidad de resolución o acto administrativo

No. De Expediente: 03488-2011-0-1801-JR-CA-16

Resumen:

El caso trata de una empresa que interpone una demanda de Nulidad de Resolución

Administrativa contra el Instituto de Defensa de la Competencia y de la Protección de la Propiedad Intelectual - INDECOPI y otros, por lo fundamentos que se detallan en el expediente. 